\title{
PERSEPSI GURU TERHADAP PELAKSANAAN KURIKULUM 2013
}

\author{
Kabiba, Junaidin, Intan Irwana \\ Universitas Muhammadiyah Kendari \\ wabiba64@gmail.com
}

\begin{abstract}
ABSTRAK
Penerapan kurikulum 2013 memunculkan tanggapan dari berbagai kalangan, terutama bagi para guru, karena banyak guru yang tidak memahami dan mengerti pelaksaan kurikulum 2013 sehingga berdasarkan kondisi tersebut peneliti tertarik untuk mengetahui tanggapan para guru terhadap penerapan kurikulum 2013. Oleh karena itu, fokus penelitian ini adalah Bagaimana persepsi guru terhadap pelaksanaan Kurikulum 2013 yang berada di SD Negeri 6 Poasia, Kendari? dengan sub fokus; pelaksanaan kuirkulum 2013, persipsi guru, administrasi pembelajaran dan sarana pendukung pembelajaran guru dan siswa. Penelitian ini adalah penelitian kualitatif dengan jenis deskriptif, yakni suatu bentuk penelitian yang memberikan gambaran mengenai objek yang di amati atau fokus penelitian.. Metode yang digunakan dalam pengambilan sampel adalah metode Purposive Sampling. Sumber data guru yang mengajar di SD Negeri 6 Poasia, Kota Kendari, berjumlahnya 12 orang sebagai informan utama dan dan termaksud kepala sekolah serta Wakil Kepala Sekolah. Berdasarkan analisis data, diperoleh kesimpulan terkait persepsi guru dalam pelaksanaan kurikulum 2013 di SDN 06 Poasia Kota Kendari adalah perencanaan, pelaksanaan dan evaluasi hasil belajar siswa serta sarana dan prasarana. Perencanaan meliputi penyusunan silabus dan RPP dalam memulai pembelajaran, Pelaksanaan meliputi kegiatan inti dalam proses belajar mengajar sedangkan evaluasi meliputi penilaian hasil belajar dan memberikan remedial pada siswa. Pelaksanaan kurikulum 2013 di SD Negeri 6 Poasia Kota Kendari masih memiliki kekurangan seperti sarana dan prasarana yang kurang memadai serta waktu jam mengajar yang bertambah sehingga guru cenderung belum maksimal dalam menerapkan kurikulum 2013 di SD Negeri 6 Poasia Kota Kendari.
\end{abstract}

Kata Kunci: Persepsi Guru, Kurikulum 2013.

\section{ABSTRACT}

The implementation of the 2013 curriculum raises responses from various groups, especially for teachers, because many teachers do not understand the implementation of curriculum 2013 so based on these conditions researchers interested in knowing the teacher's response to the implementation of the curriculum 2013. Therefore, the focus of this study is How the teacher's perception towards the implementation of Curriculum 2013 located in SD Negeri 6 Poasia, Kendari? with sub focus; implementation of curriculum 2013, teacher persipsi, instructional administration and supporting facilities for learning of teachers and students. This research is a qualitative research with descriptive type, which is a form of research that gives an idea about the observed object or research focus. The method used in sampling is Purposive Sampling method. The data source of teachers who teach at SD Negeri 6 Poasia, Kendari City, amounted to 12 people as the main informant and and meant the principal and Vice Principal. Based on data analysis, the conclusion related to teacher perception in the implementation of curriculum 2013 in SDN 06 Poasia Kendari City is planning, implementation and evaluation of student learning outcomes and facilities and infrastructure. Planning involves the preparation of syllabus and lesson plans for learning, Implementation includes core activities in the learning process while evaluation includes assessment of learning outcomes and remedial delivery to students. Implementation of the 2013 curriculum at SD Negeri 6 Poasia Kendari still has shortcomings such as inadequate facilities and infrastructure as well as increasing teaching hours so that teachers tend not maximal in applying the 2013 curriculum in SD Negeri 6 Poasia Kendari City.

Keywords: Teacher's Perception, Curriculum 2013. 


\section{PENDAHULUAN}

Kurikulum merupakan salah satu komponen penting dalam penyelenggaraan pendidikan. Secara umum kurikulum adalah suatu alat untuk mencapai tujuan pendidikan serta pedoman dalam pelaksanaan pengajaran pada semua jenis dan tingkat pendidikan di Indonesia. Kurikulum digunakan sebagai acuan penyelenggaraan pendidikandan indikator mutu pendidikan misalnya rancangan kerja, kalender akademik, dan perangkat pembelajaran. Namun, perbedaan kurikulum dapat memberikan pengaruh yang kurang baik terhadap guru, sebab perubahan kurikulum akan memberikan dampak terhadap kinerja guru dalam proses belajar mengajar.

Penggunaan kurikulum yang dimaksud adalah Kurikulum 2013. Pada dasarnya penerapan kurikulum 2013 memiliki masalah yang dihadapi dan erat kaitannya dengan pelaksanaan di sekolah. Penerapan kurikulum 2013 memunculkan persepsi di kalangan guru. Sebab banyak guru yang tidak memahami dan mengerti pelaksaan kurikulum 2013, sehingga banyak guru tidak optimal dalam mengajar di sekolah. Menurut Sukmadinata (2001) mengungkapkan bahwa hambatan utama dalam pengembangan kurikulum di sekolah terletak pada guru, diantaranya kurangnya persepsi yang positif terhadap kurikulum dankemampuan guru itu sendiri. Perbedaan persepsi guru terhadap kurikulum akan berpengaruh pada hasil penerjemahan SI dan SKL.

Faktor lain yang mempengaruhi penyusunan kurikulum 2013 adalah dukungan sarana dan prasarana yang memadai terutama ruang kegiatan pembelajaran, laboratorium, alat bantu pelajaran, sumber belajar maupun lingkungan sekolah. Guru hendaknya mampu mengkondisikan keadaan yang ada di sekolah tersebut untuk mengembangkan kurikulum 2013 sesuaidengankebutuhan dan kondisi sekolah. Persepsi guru seperti perencanaan, pelaksanaan pembelajaran, buku, sarana dan prasarana dalam pelaksanaan kurikulum 2013 masih terbilang kurang. Sebagian menilai bahwa penerapan kurikulum 2013 tidak sesuai dengan sistem pendidikan sekarang, sebab kurikulum 2013 hanya menerapkan pembelajaran berdasar pada penerapan keterampilan pada siswa, tidak pada kepribadian.

Undang-Undang Nomor 20 Tahun 2003 tentang Sistem pendidikan nasional menyebutkan bahwa kurikulum adalah seperangkat rencana dan pengaturan mengenai tujuan, isi, dan bahan pelajaran serta cara yang di gunakan sebagai pedoman pedoman penyelenggaraan kegiatan pembelajaran untuk mencapai tujuan pendidikan tertentu (Permendikbud, 2013: 1) tentang kerangka dasar dan struktur kurikulum. Menurut Hilda Taba dalam Nasution

(2009:7) 
mengemukakan, bahwa pada hakikatnya tiap kurikulum merupakan suatu cara untuk mempersiapkan anak agar berpartisipasi sebagai anggota yang produktif dalam masyarakatnya. Tiap kurikulum, bagaimanapun polanya, selalu mempunyai komponenkomponen tertentu, yakni pernyataan tentang tujuan dan sasaran, seleksi dan organisasi bahan dan isi pelajaran, bentuk dan kegiatan belajar mengajar dan akhirnya evaluasi hasil belajar.

Poerwati (2013: 4) mengatakan berbagai tafsiran tentang kurikulum dapat kita tinjau dari segi lain, sehingga kita peroleh penggolongan sebagai berikut:

1. Kurikulum dapat dilihat sebagai produk, yakni sebagai hasil karya para pengembangan kurikulum, biasanya dalam suatu panitia.

2. Kurikulum pula yang dipandang sebagai program, yakni alat yang dilakukan oleh sekolah untuk mencapai tujuannya.

3. Kurikulum dapat di pandang sebagai hal-hal yang diharapkan akan di pelajari siswa, yakni pengetahuan, sikap, keterampilan tertentu.

4. Kurikulum sebagai pengalaman siswa. Ketiga pandangan di atas berkenaan dengan perencanaan kurikulum sedang pandangan ini mengenai apa yang secara aktual menjadi kenyataan pada setiap siswa.
Simpulan dari penjelasan diatas dapat penulis katakan bahwa kurikulum adalah seperangkat rencana pengajaran yang digunakan guru sebagai pedoman dalam kegiatan belajar mengajar di sekolah untuk mencapai tujuan pendidikan.

Kurikulum 2013 ini berbasis kompetensi sekaligus berbasis karakter. Pendidikan karakter dalam Kurikulum 2013 bertujuan untuk meningkatkan mutu proses dan hasil pendidikan, yang mengarah pada pembentukan budi pekerti dan akhlak mulia peserta didik secara utuh, terpadu, dan seimbang, sesuai dengan standar kompetensi lulusan pada setiap satuan pendidikan (Mulyasa, 2013:7). Berdasarkan pengertian tersebut terdapat dua dimensi kurikulum, yang pertama adalah rencana dan pengaturan mengenai tujuan, isi, dan bahan pelajaran, sedangkan yang kedua adalah cara yang digunakan untuk kegiatan pembelajaran.

Kurniasih Imas dan Berlin Sani (2014: 32) mengemukakan Kurikulum 2013 merupakan serentetan rangkaian penyempurnaan terhadap kurikulum yang telah dirintis tahun 2004 yang berbasis kompetensi lalu diteruskan dengan kurikulum 2006 (KTSP). Kurikulum 2013 merupakan lanjutan pengembangan kurikulum berbasis kompetensi yang telah dirintis pada tahun 2004 dengan mencakup kompetensi sikap, pengetahuan, dan keterampilan secara terpadu (Hidayat, 2013: 113). 
Oemar Hamalik (1990: 8) berpendapat bahwa ada tiga peranan kurikulum yang dinilai sangat penting dalam penyelenggaraan pendidikan di sekolah. Ketiga peranan tersebut adalah: 1) peranan konservatif, 2) peranan kritis atau evaluatif dan 3) peranan kreatif. Ketiga peranan ini sama pentingnya dan diantara ketiganya perlu dilaksanakan secara berkeseimbangan.

Menurut Peraturan Menteri Pendidikan Dan Kebudayaan Republik Indonesia Nomor 69 Tahun 2013, Kurikulum 2013 dilihat dalam melalui landasan filosofis, yuridis dan konseptual. Pelaksanaan kurikulum 2013 dalam pada implementasinya tentunya menuai banyak tanggapan terutama dari kalangan guru-guru, disebabkan oleh proses belajar mengejar guru dengan perkembangan kuriulum 2013 dihadapkan pada tantangan permasalahan yang dapat menghambat pembelajaran dikelas, seperti perencanaan pembelajaran, pelaksanaan pembelajaran, maupun ketersediaan sarana prasarana di kelas. Berdasarkan narasi di atas, rumusan masalah dalam penelitian ini adalah "Bagaimanakah Persepsi Guru terhadap Pelaksanaan Kurikulum 2013 di SD Negeri 6 Poasia Kendari?"

\section{METODE PENELITIAN}

Jenis penelitian ini adalah deskriptif kualitatif, yakni suatu bentuk penelitian yang memberikan gambaran mengenai tanggapan tertulis atau lisan dari orang-orang atau perilaku yang dapat diamati terhadap status kelompok manusia , suatu objek, atau suatu kelompok kebudayaan. Penelitian ini dilaksanakan di SD Negeri 6 Poasia Kota Kendari, pada bulan November sampai dengan Desember 2017. Penelitian ini difokuskan pada konteks analisis persepsi, dengan sub fokus; pelaksanaan kuirkulum 2013, persipsi guru, administrasi pembelajaran dan sarana pendukung pembelajaran guru dan siswa. Metode yang digunakan dalam pengambilan sampel adalah metode Purposive Sampling. Populasi dalam penelitian ini adalah berjumlah 12 guru yang mengajar di SDN 06 Poasia, sedangkan sampel berjumlah 6 orang.

Pengumpulan data dan informasi di lapangan menggunakan teknik;

1. Observasi, yaitu melakukan pengamatan langsung dilapangan terutama berkaitan dengan data penelitian yang diperlukan, sedangkan yang diobservasi dalam penelitian ini adalah bagaimana persepsi guru dalam pelaksanaan Kurikulum 2013 di SD Negeri 6 Poasia Kota Krndari.

2. Wawancara. Bentuk wawancara yang dilakukan adalah wawancara berstruktur dan wawancara tidak berstruktur, wawancara berstruktur dilakukan untuk memperoleh data pokok. 
Wawancara mendalam dilakukan dengan wawancara yangbersifat lentur dan terbuka, tidak berstruktur ketat, tidak pada suasana formal dan dilakukan berulang-ulang pada informan yang sama.

3. Dokumentasi. Dokumentasi bertujuan untuk memberikan gambaran mengenai proses dalam penelitian melalui studi pustaka. teknik analisis data yakni data yang telah dikumpulkan, diolah dan menggunakan penelitian kualitatif serta analisis domain untuk memperoleh gambaran umum dan menyeluruh pada objek dengan menerangkan teknik analisis selama di lapangan, dan dilakukan secara interaktif melalui proses data reduksi, data display dan verification (miles and huberman 1984) dikutip sugiyono 2010 : 294). Rencana pengujian keabsahan data penulis menggunakan uji kredibilitas data dengan perpanjangan pengamatan keikutsertaan, triangulasi, diskusi dengan teman sejawat. Pengujian transferability, dependability, dan pengujian konfirmability. (sugiyono 2010: 368-377).

\section{HASIL PENELITIAN}

\section{Persepsi Guru dalam} Perencanaan Kurikulum 2013

Kurikulum 2013 yang dilakukan oleh pemeintah kota Kendari di setiap sekolah-sekolah hampir sebagian besar dapat dilaksanakan dengan baik, karena faktor guru yang dapat bekerja dalam kegiatan belajar mengajar. Pelaksanaan kurikulum 2013 di SDN 06 Poasia dapat dikategorikan berjalan dengan baik karena sistem yang dianut juga berjalan dengan sesuai kriteria yang ditetapkan kurikulum 2013.

Perencanaan pembelajaran yang dilakukan oleh guru di Sekolah Dasar Negeri (SDN) 06 Poasia, Kota Kendari sudah sangat berjalan dengan baik, dimana setiap guru yang akan mengajar harus menyusun Rencana Pelaksanaan Pembelajaran (RPP). Pelaksaan pembelajaran kurikulum 2013 di Sekolah Dasar Negeri (SDN) 06 Poasia, Kota Kendari sudah sesuai dengan ketentuan dari kurikulum 2013.

Hasil wawancara kepala sekolah SDN 06 Poasia Kota Kendari sangat mementingkan penerapan kurikulum 2013 melalui dengan pengelolaan kurikulum yang melibatkan guru dan siswa dalam proses belajar mengajar di sekolah. Perencanaan pembelajaran yang berbasis pada kurikulum 2013 mencakup pada penyususnan RPP dan mengalokasikan waktu yang digunakan. Namun, perencanaan yang dilakukan harus sesuai dengan kriteria kurikulum 2013. Sebagian besar guru belum memahami tentang kurikulum 
2013 dengan kurikulum tingkat satuan pendidikan (KTSP) sehingga menjadi timpang tindih dalam mengaplikasikan dalam proses belajar mengajar.

Dari uraian mengenai hasil wawancara dapat disimpulkan bahwa Sekolah Dasar Negeri (SDN) 06 Poasia berusaha yang melakukan dengan maksimal kurikulum 2013, walaupun pro dan kontra dalam pelaksanaan masih menimbulkan polemic dikalangan guru. Karena sebagian guru menyatakan bahwa kurikulum 2013 lebih baik disbanding kurikulum tingkat satuan pendidikan, sebab kurikulum 2013 akan lebih memudahkan siswa dalam proses belajar mengajar, karena siswa ditekankan untuk mampu memahami dan mengerti dari pelajaran yang diberikan.

\section{Persepsi Guru dalam Pelaksanaan} Kurikulum 2013

Pelaksanaan kurikulum 2013 kepala sekolah haruslah lebih sangat disiplin meninjau dan mengontrol jalannya kurikulum 2013 di sekolah kemampuan yang sangat baik agar sekolah tersebut bias lebih aktif karena kepala sekolah melakukan tugasnya dengan baik. Pelaksanaan kurikulum 2013 di sekolah dasar (SDN) 06 Poasia dapat dikategorikan baik. Namun, berbagai kendala dapat menghambat jalannya kurikulum 2013. Kurikulum 2013 menuntut kepada guru untuk lebih berperan aktif dalam proses belajar mengajar di sekolah.

Hambatan yang didapatkan dalam pelaksanaan kurikulum 2013 karena keadaan siswa itu sendiri, dimana siswa lebih cendrung untuk selalu bermain sehingga pelaksanaan proses belajar mengajar di kelas dapat tidak maksimal dilakukan oleh guru. Selain itu pula ketersedian sarana dan prasarana turut memberikan hambatan dalam pelaksanaan kurikulum 2013 sebab sarana dan prasarana yang baik akan memberikan pengaruh positif yang baik pula.

Pelaksanaan kurikulum 2013 di sekolah dasar SDN 06 Poasia Kota Kendari hampir sama dengan sekolah-sekolah pada umumnya. Dimana setiap sekolah akan melakukan perencanaan pembelajaran, pelaksanaan pembelajaran setelah itu akan melakukan evaluasi hasil dari pembelajaran. Hidayat (2013:158) menjelaskan bahwa "implementasi kurikulum adalah bagaimana membelajarkan pesan dalam kurikulum kepada siswa agar dapat menghasilkan lulusan yang memiliki seperangkat kompetensi sesuai dengan karakteristik dan kemampuan siswa masing-masing". 


\section{Persepsi Guru dalam Evaluasi Hasil Pembelajaran}

Evaluasi hasil belajar yang dilakukan oleh guru dalam guna untuk mengetahui pelajaran yang diberikan selama proses belajar mengajardilakukan. Pelaksanan evaluasi akan memberikan gambaran kepada guru bahwa pelajar yang diajarkan selama ini mampu untuk dipahami atau tidak. Selain itu pula, akan menjadi evaluasi untuk guru yang mengajar di SDN 06 Poasia bias berbentuk tanya jawab, penyedia soal belajar dan penilaian individu serta kelompok serta tertulis dan tidak tertulis selama proses belajar mengajar dilakukan.

Hasil wawancara dari para informan dapat disimpulkan bahwa setiap guru yang mengajar selalu melakukan evaluasi dari hasil belajar yang dilakukan. Karena dengan evaluasi seorang guru mampu mengetahui hasil atau tidak dalam mengajarkan pelajaran yang dilakukan di kelas.

\section{PEMBAHASAN}

\section{Persepsi \\ Guru \\ Dalam}

Perencanaan Pembelajaran

Persepsi guru terhadap kendala-kendala dalam pelaksanan Kurikulum 2013 di SDN 06 PoasiaKota Kendari merupakan peresepsi terhadap kendalakendala selama pelaksanaan kurikulum 2013 ini. Aspek-aspek yang terdapat dalam kendala- kendala tersebut antar lain : kurangnya sosialisasi kurikulum 2013 terhadap guru, kurangnya respon yang baik dari siswa, kurangnya respon yang baik dari masyarakat, dan kurangnya dukungan dari sekolah terhadap pelaksanaan kurikulum 2013.

Dalam penelitian ini, persepsi guru bermacam-macam terhadap kendala-kendala dalam pelaksanaan kurikulum 2013 di SDN 06 Poasia Kota Kendari. Hilda Taba dalam Nasution (2009:7) mengemukakan, bahwa pada hakikatnya tiap kurikulum merupakan suatu cara untuk mempersiapkan anak agar berpartisipasi sebagai angota yang produktif dalam masyarakat. Selanjutnya Jamal (2010: 39-54) menyebutkan ada beberapa peran dan tugas guru, yaitu (1) pendidik, (2) Pemimpin, (3) Fasilitator, (4) Motivator, (5) Administrator, dan (6) Evaluator. Namun, pada dokumen Silabus dan Rencana Pelaksanaan Pembelanjaan (RPP) di SDN 06 Poasia Kota Kendari belum tertera metode pembelajaran pendekatan ilmiah (Scientifik approach). Metode yang terdapat dalam metode pembelajaran tersebut adalah metode ceramah dan metode tanya jawab. Seharusnya di dalam Rencanaan

Pelaksanaan Pembelajaran (RPP) tersebut dicantumkan metode pendekatan ilmiah (Scientifik approach) karena 
pada kurikulum 2013 metode yang

digunakan dalam proses

pembelajaran adalah

menggunakan metode

pendekatan ilmiah (Scientifik

approach).

Menurut Sudjana (1998: 48)

menyatakan bahwa perencanaan pembelajaran merupakan kegiatan memproyeksikan tindakan apa yang akan dilaksanakan dalam suatu kegiatan belajar mengajar yaitu dengan mengkoordinasikan (mengatur dan merespon) komponenkomponen pembelajaran, sehingga arah kegiatan (tujuan), isi kegiatan (materi), cara penyampaian kegiatan (metode dan teknik), serta bagaimana mengukurnya (evaluasi) menjadi jelas dan sistematis.

\section{Pelaksanaan}

Persepsi guru terhadap proses pembelajaran kurikulum 2013 di SDN 06 Poasia, Kota Kendari merupakan persepsi terhadap pelaksanaan proses pembelajaran yang berlangsung di kelas. Aspek-aspek yang terdapat dalam proses pembelajaran tersebut antara lain : perencanaan pembelajaran, proses pembelajaran, kegiatan pendahuluan, kegiatan inti dan kegiatan penutup. Dalam penelitian ini, guru memberikan respon yang sangat positif terhadap aspek-aspek terhadap proses pembelajaran di SDN 06 Poasia, Kendari. Nana Sudjana (2010: 136), pelaksanaan pembelajaran adalah "proses yang diatur sedemikian rupa menurut langkah-langkah tertentu agar pelaksanaan mencapai hasil yang diharapkan." Sedangkan menurut Syaiful Bahri dan Aswan Zain (2010: 111), pelaksanaan pembelajaran adalah "suatu kegiatan yang bernilai edukatif, nilai edukatif mewarnai interaksi yang terjadi antara guru dan siswa.

Persepsi guru terhadap pelaksanaan di SDN 06 Poasia, Kota Kendari merupakan persepsi terhadap cara penilaian guru kepada peserta didik. Aspek-aspek yang terdapat dalam penilaian tersebut antara lain : penilaian terhadap hasil belajar dan penilaian sikap serta pengetahuan. Dalam hal ini guru memberikan respon positif terhadap aspekaspek pada siswa di SDN 06 Poasia, Kota Kendari. Menurut Mulyasa Mulyasa, (2013:7)Pendidikan karakter dalam Kurikulum 2013 bertujuan untuk meningkatkan mutu proses dan hasil pendidikan, yang mengarah pada pembentukan budi pekerti dan akhlak mulia peserta didik secara utuh, terpadu, dan seimbang, sesuai dengan standar kompetensi lulusan pada setiap satuan pendidikan. 
Pelaksanaan pembelajaran di kelas yang sesuai silabus serta RPP akan berjalan dengan baik apabila sarana dan prasarana yang dibutuhkan mendukung dalam hal proses belajar mengajar. Sarana dan prasarana yang baik akan memberikan dampak yang besar dalam peningkatan minat belajar siswa, karena siswa akan cendrung lebih nyaman dalam belajar apa bila ketersedian buku, gedung dan ruangan cukup memadai, namun sarana dan prasaran yang buruk akan memberikan pengaruh terhadap proses blajar dikelas. Kurangnya sarana dan prasarana akan menyebabkan rendahnya minat dalam belajar, keinginan siswa untuk belajar namun tidak tersedianya ruangan dan buku dalam menunjang akan menyebabkan siswa malas dalam membaca sehingga kan mempengaruhi daya minat belajar siswa. Hal ini terjadi di SDN 06 Poasia Kota Kendari, dimana siswa sangat aktif dalam belajar di ruangan. Sebab ketersedian sarana dan prasarana cukup memadai seperti buku, ruangan, lab belajar sehingga siswa akan cendrung lebih nyaman.

\section{Evaluasi}

Persepsi guru terhadap pelaksanaan kurikulum 2013 di SDN 06 Poasia, Kota Kendari merupakan persepsi terhadap penilaian yang terdapat dalam kurikulum 2013, yaitu : Penilaian

Sikap, pengetahuan dan keterampilan. Hal ini sesuai dengan Peraturan Menteri Pendidikan Nomor 66 Tahun 2013 tentang standar penilaian pendidikan. Di dalam peraturan tersebut disebutkan bahwa standar penilaian pendidikan adalah criteria mengenai mekanisme, prosedur dan instrument penilaian hasil belajar peserta didik. Tujuan dari standar penilaian antara lain untuk menjamin : a) perencanaan penilaian peserta didik sesuai dengan kompetensi yang akan di capai dan berdasarkan prinsipprinsip penilaian, b) pelaksanaan penilaian peserta didik secara professional, terbuka, edukatif, efektif, efisien, dan sesuai dengan konteks social budaya, c) pelaporan hasil penilaian peserta didik secara objektif, akuntabel dan informatif. Standar penilaian disusun sebagai acuan bagi pendidik, satuan pendidikan dan pemerintah pada satuan pendidikan untuk jenjang pendidikan dasar dan menengah. Hal ini senada dengan hasil penelitian yang telah diungkapakan pada hasil penelitian sebelumnya.

\section{KESIMPULAN}

Berdasarkan hasil penelitian dapat ditarik kesimpulan bahwa pelaksanaan kurikulum 2013 di SDN 
06 Poasia Kota Kendari meliputi Perencanaan, Pelaksanaan dan Evaluasi hasil belajar siswa serta sarana dan prasarana. Perencanaan meliputi penyusunan silabus dan RPP dalam memulai pembelajaran, Pelaksanaan meliputi kegiatan inti dalam proses belajar mengajar sedangkan evaluasi meliputi penilaian hasil belajar dan memberikan remedial pada siswa. Pelaksanaan kurikulum 2013 di SD Negeri 6 Poasia Kota Kendari sudah berjalan dengan baik akan tetapi masih ada kekurangan baik dalam hal sarana dan prasarana yang mendukung pelaksanaan kurikulum 2013 di SD Negeri 6 Poasia Kota Kendari.

\section{DAFTAR PUSTAKA}

Ansori, I. 2015. Persepsi Guru Dalamimplementasi Kurikulum 2013di Sekolah Dasar Negeri 07 Kauman BatangTahun Pelajaran 2014/2015. Fakultas Keguruan Dan Ilmu Pendidikan. Universitas Muhammadiyah Surakarta. Surakarta.

Arifin, R. 2014. Persepsi Guru Terhadap Implementasi Kurikulum 2013 Bidang Keahlian Teknik Bangunan Di SMK Negeri 2 Yogyakarta. Fakultas Teknik. Universitas Negeri Yogyakarta.

Ciptasari, I, N. 2015. Persepsi Guru Terhadap Pelaksanaan Kurikulum 2013 Pada Mata Pelajaran Sejarah (Studi Kasus Guru Sejarah di SMAN 1 Sawan). Fakultas Ilmu Sosial.
Universitas

Pendidikan Ganesha Singaraja

Hamalik, A. 2002, Pendidikan Guru Berdasarkan Kompetensi, Cet ke-7. Jakarta : PT. Bumi Aksara

Moleong, L, J. 2006. Metodologi Penelitian Kualitatif: Edisi Revisi. PT. Remaja Rosdakarya. Bandung.

Mulyasa, 2006. Menjadi Guru Profesional. Bandung: Rosda Karya.

Nawawi, Hadari. 2005. Metode Penelitian Bidang Sosial. Yogyakarta: Gadjah Mada University Press

Peraturan Menteri Pendidikan Nasional RI Nomor 22 Tahun 2006.

Sanjaya, Wina. 2008. Kurikulum dan Pembelajaran. Bandung: Kharisma Putra

Standar Isi.

Sugiyono. 2014. Metode penelitian kuantitatif kualitatif dan R \& D. Bandung: Alfabeta.

Sukmadinata. 2001. Pengembangan Kurikulum. Bandung: PT. Remaja Rosda Karya.

Sutopo, H.B. 2006. Metodologi Penelitian Kualitatif. Surakarta: Universitas Sebelas Maret

Umaedi. 2001. Manajemen Berbasis Sekolah Untuk Sekolah Dasar. Jakarta: Dirjen Dikdasmen Utama. 